Artikel Penelitian

\title{
Pendidikan Kesehatan Mempengaruhi Perilaku Remaja Terhadap Pencegahan Keputihan Patologis
}

\author{
Fauziah Yulfitria*, Karningsih, Mardeyanti, Elly Dwi Wahyuni, Theresia EVK \\ Program Studi DIII Kebidanan, Jurusan Kebidanan, Poltekkes Kemenkes Jakarta III, Indonesia \\ *Corresponding author: zye_ajja@yahoo.com
}

\begin{abstract}
Background: Vaginal discharge is a physiological problem often experienced by women. When vaginal discharge happens, women are expected to have a healthy lifestyle to prevent pathological vaginal discharge. Several studies found that most adolescents had poor behavior in preventing pathological vaginal discharge. The provision of health education is an effort to prevent the occurrence of pathological vaginal discharge. Purposes: how health education can prevent pathological vaginal discharge. Methods: semi-experimental with a pre-test post-test design, a sample of 150 people, consisting of an intervention group of leaflet media health education, group of a PowerPoint slide media health education, and a control group, using primary data and univariate and bivariate analysis. Results: health education media leaflets and PowerPoint slides can improve adolescent behavior in preventing pathological vaginal discharge. Conclusion: health education can influence the behavior of preventing pathological vaginal discharge.
\end{abstract}

Keywords: pathological vaginal discharge, health education, behavior

\begin{abstract}
ABSTRAK
Latar Belakang: Keputihan merupakan masalah fisiologis yang sering dialami oleh perempuan. Pada saat keputihan, diharapkan perempuan memiliki perilaku hidup sehat untuk mencegah terjadinya keputihan patologis. Dari beberapa penelitian, didapatkan sebagian besar remaja memiliki perilaku yang kurang baik dalam pencegahan keputihan patologis. Pemberian pendidikan kesehatan merupakan upaya untuk mencegah terjadinya keputihan patologis. Tujuan: Bagaimana pendidikan kesehatan dapat mempengaruhi perilaku pencegahan keputihan patologis. Metode: Semi eksperimen dengan desain pre-test post-test, sampel 150 orang, terdiri dari kelompok intervensi pendidikan kesehatan media leaflet, pendidikan kesehatan media slide power point dan kelompok kontrol. Menggunakan data primer dan analisis univariat serta bivariat. Hasil: Pendidikan kesehatan media leaflet dan slide power point dapat meningkatkan perilaku remaja dalam mencegah keputihan patologis. Simpulan: pendidikan kesehatan dapat mempengaruhi perilaku pencegahan keputihan patologis.
\end{abstract}

Kata kunci: keputihan patologis, pendidikan kesehatan, perilaku 


\section{PENDAHULUAN}

Keputihan adalah keluarnya cairan yang bukan darah dari jalan lahir dengan ciri khas dapat berbau atau tidak, berwarna atau tidak, kental atau encer dan disertai gatal atau tidak. Keputihan terdiri dari dua kategori, yaitu normal (fisiologis) dan tidak normal (patologis). Keputihan fisiologis disebabkan oleh faktor hormonal, sedangkan keputihan patologis disebabkan oleh infeksi genitalia, benda asing atau penyakit lain pada organ reproduksi (1). Untuk mencegah terjadinya keputihan patologis, maka perlu dilaksanakan perilaku hidup sehat, terutama pada masa remaja, karena pada masa remaja terjadi perkembangan organ reproduksi sehingga organ reproduksi lebih sensitif. Keputihan patologis dapat menimbulkan rasa yang tidak nyaman dan jika dibiarkan dalam jangka waktu lama bisa menyebabkan penyakit serius seperti penyakit infeksi panggul, infertilitas, kehamilan diluar kandungan dan juga merupakan gejala awal dari kanker serviks. Ada beberapa faktor yang menghambat untuk berperilaku sehat dalam mencegah keputihan patologis, yaitu rendahnya pengetahuan individu remaja tentang pencegahan keputihan, sikap yang tidak tepat yang memperlemah motivasi seseorang untuk berperilaku hidup sehat $(1,2)$.

Hasil penelitian Yulfitria F (2015), didapatkan angka kejadian keputihan fisiologis pada mahasiswa kebidanan Jakarta sebesar $98 \%$ dan 20, $4 \%$ mahasiswa pernah mengalami keputihan patologis dengan gejala keputihan yang disertai gatal dan sedikit berbau. 39,8\% mahasiswa memiliki perilaku pencegahan keputihan yang kurang baik, 29,6 \% memiliki pengetahuan kurang dan 55,4\% memiliki sikap yang negatif mengenai pencegahan keputihan patologis (2).
Perilaku pencegahan keputihan patologis (fluor albus), sangat dipengaruhi oleh pengetahuan remaja. Susanto (2016) mengatakan bahwa informasi yang diperoleh, dapat memungkinkan seseorang untuk menyerap nilai-nilai dan pengetahuan yang bisa mempengaruhi pola pikir dan tindakannya. Salah satu sumber informasi seseorang adalah melalui pendidikan kesehatan. Pendidikan kesehatan dapat menggunakan media cetak seperti poster, leaflet, brosur, majalah, surat kabar, stiker dan pamflet, maupun media elektronik seperti $\mathrm{TV}$, radio, cassette dan slide. Leaflet dan slide powerpoint merupakan media yang sederhana, mudah, murah dan sering digunakan oleh tenaga kesehatan dalam memberikan pendidikan kesehatan (3).

Pemberian pendidikan kesehatan kepada remaja mengenai pencegahan keputihan patologis, diharapkan remaja memiliki perilaku yang baik dalam melakukan pencegahan keputihan, sehingga tidak akan timbul masalahmasalah akibat keputihan patologis, seperti masalah ketidaknyamanan pada organ intim, keputihan yang berbau dan berwarna, serta beberapa penyakit serius diantaranya penyakit infeksi panggul, infertilitas bahkan kanker serviks

Penelitian ini bertujuan untuk mengetahui bagaimana pendidikan kesehatan dapat mempengaruhi perilaku pencegahan keputihan patologis.

\section{METODE}

Penelitian ini menggunakan metode semi eksperimen dengan desain pre-test dan post-test. Pertama-tama dilakukan pengukuran dengan membagikan kuesioner, lalu satu kelompok tidak diberikan perlakukan dan dua kelompok diberikan perlakuan yaitu berupa 
pemberian materi pendidikan kesehatan, satu kelompok dengan menggunakan media leaflet dan satu kelompok menggunakan media slide powerpoint, satu bulan kemudian kuesioner dibagikan kembali pada kelompok responden yang sama. Penelitian ini menggunakan sampel seluruh mahasiswi tingkat I Prodi D III Kebidanan Poltekkes Kemenkes Jakarta III TA 20162017 berjumlah 150 orang. Sampel dibagi menjadi tiga kelompok, dengan pemilihan sampel berdasarkan purposive sampling. Penelitian ini menggunakan kuesioner perilaku sebagai alat untuk pengumpulan data. Analisa data univariat dengan distribusi frekuensi dan analisa bivariat dengan independent T-Test. Persetujuan etik penelitian ini didapatkan dari Komisi Etik Penelitian Kesehatan Politeknik Kesehatan Kemenkes Jakarta III (KEPKPKKJ3) dengan No. 071/KEPKPKKJ3/05/2016.

\section{HASIL}

Penelitian yang sudah dilakukan disajikkan dalam bentuk tabel sebagai berikut :

Tabel 1. Karakteristik Responden

\begin{tabular}{lcc}
\hline Karakteristik & Jumlah & \% \\
\hline Umur & & \\
$<18$ thn & 33 & 22 \\
$\geq 18$ thn & 117 & 78 \\
Umur Menarche & & \\
$<13$ tahun & 73 & 49 \\
$\geq 13$ tahun & 77 & 51 \\
Mengalami Keputihan & \\
Pernah & 150 & 100 \\
Tidak Pernah & 0 & 0 \\
Keputihan Patologis (Fluor Albus) \\
Pernah & 125 & 83 \\
Tidak Pernah & 25 & 17 \\
\hline Jumlah & 150 & 100 \\
\hline
\end{tabular}

Analisa data Tabel 1: $78 \%$ mahasiswa Kebidanan Jakarta berumur $\geq 18$ tahun dan mayoritas mengalami menarche pada umur $\geq 13$ tahun, yaitu sekitar $51 \%$. $100 \%$ mahasiswa Kebidanan Jakarta pernah mengalami keputihan fisiologis dan $83 \%$ pernah mengalami keputihan patologis.

Tabel 2. Waktu Mengalami Keputihan

\begin{tabular}{lcc}
\hline \multicolumn{1}{c}{ Variabel } & Jumlah & \% \\
\hline Sebelum Haid & & \\
Ya & 129 & 86 \\
Tidak & 21 & 14 \\
Sesudah Haid & & \\
Ya & 54 & 36 \\
Tidak & 96 & 64 \\
Saat Memakai Pakaian Ketat & \\
Ya & 5 & 3 \\
Tidak & 145 & 97 \\
Kelelahan & & \\
Ya & 53 & 35 \\
Tidak & 97 & 65 \\
\hline Jumlah & 150 & 100 \\
\hline
\end{tabular}

Analisa data tabel 2: mahasiswa kebidanan Jakarta mengalami keputihan pada saat sebelum Haid (86\%), pada saat sesudah Haid $(36 \%)$, pada saat memakai pakaian ketat (3\%) dan pada saat kelelahan (35\%).

Tabel 3. Tanda-tanda Keputihan Patologis

\begin{tabular}{lcc}
\hline \multicolumn{1}{c}{ Variabel } & Jumlah & \% \\
\hline Gatal & & \\
Pernah & 102 & 82 \\
Tidak Pernah & 23 & 18 \\
Berbau & & \\
Pernah & 56 & 45 \\
Tidak Pernah & 69 & 55 \\
Berwarna & & \\
Pernah & 29 & 23 \\
Tidak Pernah & 96 & 77 \\
Panas & & \\
Pernah & 2 & 2 \\
Tidak Pernah & 123 & 98 \\
\hline Jumlah & 125 & 100 \\
\hline
\end{tabular}

Analisa data tabel 3: mahasiswa kebidanan Jakarta pernah mengalami keputihan patologis (fluor albus) dengan tanda-tanda 
gatal $(82 \%)$, berbau (45\%), berwarna $(23 \%)$ dan panas $(2 \%)$.

Untuk mengetahui apakah ada perbedaan perilaku pencegahan keputihan patologis sebelum dan sesudah mendapatkan pendidikan kesehatan, maka dilakukan analisa bivariat independent $\mathrm{T}$ Test dengan signifikan 5\%. Analisa bivariat independent $\mathrm{T}$-Test ini membandingkan mean dua kelompok data independent (menggunakan data numerik).

Tabel 4. Distribusi Rata-rata Perilaku Responden Sebelum dan Sesudah Pemberian Leaflet tentang Pencegahan Keputihan Patologis

\begin{tabular}{llllll}
\hline Variabel & Mean & SD & SE & P-Value & N \\
\hline Perilaku & & & & & \\
Sebelum & 31,96 & 3,13 & 0,44 & 0,005 & 50 \\
Sesudah & 32,68 & 3,52 & 0,50 & & \\
\hline
\end{tabular}

Analisa data tabel 4: rata-rata penilaian Perilaku sebelum pemberian leaflet adalah 31,96 dan sesudah pemberian leaflet 32,68. Hasil uji T-Test disimpulkan terdapat perbedaan antara perilaku sebelum dan sesudah pemberian leaflet (P-Value 0,005).

Tabel 5. Distribusi Rata-rata Perilaku Responden Sebelum dan Sesudah Pemberian Penyuluhan dengan Media Slide Power Point tentang Pencegahan Keputihan Patologis

\begin{tabular}{lccccc}
\hline Variabel & Mean & SD & SE & P-Value & N \\
\hline Perilaku & & & & & \\
Sebelum & 29,94 & 4,07 & 0,58 & 0,000 & 50 \\
Sesudah & 33,48 & 3,16 & 0,45 & & \\
\hline
\end{tabular}

Analisa data tabel 5: rata-rata penilaian Perilaku sebelum pemberian penyuluhan dengan media slide powerpoint adalah 29,94 dan sesudah pemberian Penyuluhan dengan media slide powerpoint 33,48. Hasil uji T-Test disimpulkan terdapat perbedaan antara perilaku sebelum dan sesudah pemberian penyuluhan dengan media slide power point ( $\mathrm{p}$-value 0,000).

Tabel 6. Distribusi Rata-rata Perilaku Responden Kelompok Kontrol tentang Pencegahan Keputihan Patologis

\begin{tabular}{lccccc}
\hline Variabel & Mean & SD & SE & P-Value & N \\
\hline Perilaku & & & & & \\
Tahap I & 32,20 & 3,11 & 0,44 & 0,832 & 50 \\
Tahap II & 32,12 & 3,07 & 0,43 & & \\
\hline
\end{tabular}

Analisa data tabel 6: rata-rata penilaian perilaku tahap I adalah 32,20 dan penilaian tahap II 32,12. Hasil uji T-Test disimpulkan tidak terdapat perbedaan antara perilaku tahap I dan tahap II (PValue 0,832).

Untuk mengetahui pengaruh Pendidikan Kesehatan terhadap perubahan perilaku pencegahan keputihan patologis, maka dilakukan uji Anova.

Tabel 7. Hasil Uji Pengaruh Pendidikan Kesehatan Terhadap Perubahan Perilaku Terhadap Pencegahan Keputihan Patologis

\begin{tabular}{|c|c|c|c|c|}
\hline $\begin{array}{l}\text { Pendidikan } \\
\text { Kesehatan }\end{array}$ & Mean & $\mathbf{F}$ & $\mathbf{P}$ & $\begin{array}{l}\text { Keput } \\
\text { usan }\end{array}$ \\
\hline $\begin{array}{l}\text { Sesudah Media } \\
\text { Leaflet }\end{array}$ & 32,68 & & & \\
\hline $\begin{array}{l}\text { Sesudah Media } \\
\text { Slide PowerPoint }\end{array}$ & 33,48 & 6,125 & 0,000 & $\begin{array}{c}\text { Ho } \\
\text { ditolak }\end{array}$ \\
\hline $\begin{array}{l}\text { Sesudah Tanpa } \\
\text { Media }\end{array}$ & 32,12 & & & \\
\hline
\end{tabular}

Analisa data: tabel diatas menunjukkan nilai $\mathrm{F}=6,125$ lebih besar dari pada $\mathrm{F}$ tabel dan $\mathrm{P}=0,000$, sehingga dapat disimpulkan terdapat perbedaan yang signifikan perubahan perilaku antara pendidikan kesehatan menggunakan leaflet dengan slide powerpoint $(0,000<0,05)$. Media 
slide powerpoint lebih efektif karena meannya lebih besar dari media leaflet $(33,48>32,68)$.

\section{PEMBAHASAN}

\section{Karakteristik Responden}

Dalam penelitian ini, sebagian besar responden berusia diatas 18 tahun (78\%), sehingga responden termasuk dalam kategori remaja. Masa remaja merupakan masa peralihan dari masa anak-anak kemasa dewasa, masa menemukan identitas diri. Pada masa remaja terjadi pertumbuhan fisik dan psikis yang sangat cepat, termasuk pertumbuhan organ reproduksinya. Remaja sangat membutuhkan informasi yang tepat tentang perawatan Kesehatan reproduksinya, dan jika tidak mendapatkannya maka kemungkinan dapat menyebabkan masalah pada kesehatan reproduksinya.

Sebagian besar responden, mengalami menarch pada usia diatas 13 tahun $(77 \%)$. Menarch adalah menstruasi yang pertama kali datang, terjadi pada umur 11 - 16 tahun dan merupakan kejadian yang berarti dari seorang remaja perempuan. Haid adalah perdarahan yang berasal dari uterus sebagai tanda bahwa alat reproduksinya sudah siap melaksanakan fungsinya, terjadi setiap bulan secara teratur pada seorang wanita dewasa yang sehat dan tidak hamil. Pada saat mendapatkan menstruasi untuk pertama kalinya, diharapkan perempuan tersebut dapat melakukan perawatan yang baik dan benar pada organ reproduksinya, sehingga tidak terjadi masalah pada organ reproduksinya. Usia menarche dapat dipengaruhi oleh status gizi, pola makan, status ekonomi dan aktivitas olahraga (4).

Sebanyak $100 \% \quad$ responden mengalami keputihan fisiologis. Keputihan fisiologis merupakan salah satu bentuk respon tubuh dan merupakan hal yang normal. Keputihan lebih banyak keluar ketika wanita dalam masa ovulasi menjelang menstruasi, hal ini disebabkan oleh hormone estrogen meningkat sehingga lendir vagina meningkat jumlahnya. 90\% Perempuan di Indonesia beresiko untuk mengalami keputihan, hal ini disebabkan karena negara Indonesia beriklim tropis yang mengakibatkan organ reproduksi menjadi lebih lembab dan basah sehingga memudahkan jamur untuk tumbuh dan berkembang. Keputihan fisiologis disebabkan oleh faktor hormonal, kelelahan fisik dan kejiwaan seperti stress. Hampir seluruh wanita dari berbagai usia pernah mengalami keputihan. Menurut Organisasi Kesehatan Dunia (WHO), lebih kurang $75 \%$ wanita di seluruh dunia diyakini akan mengalami keputihan 1x dalam hidup mereka dan $45 \%$ akan mengalami keputihan 2x atau lebih sedangkan untuk perempuan Eropa mengalami keputihan sebesar 25\% (1,5).

Dari hasil penelitian, didapatkan $83 \%$ responden pernah mengalami keputihan patologis (fluor albus), dan gejala yang mereka alami antara lain keputihan yang disertai gatal, sedikit berbau, berwarna dan bahkan ada yang merasa panas. Keputihan patologis terjadi akibat peradangan atau infeksi di daerah organ genitalia akibat dari perilaku yang tidak baik dalam menjaga kebersihan daerah genitalia, seperti cebok dengan menggunakan air kotor, berlebihan menggunakan cairan pembersih vagina, memakai pakaian dalam yang tidak menyerap keringat, jarang menukar pakaian dalam, jarang menukar pembalut disaat menstruasi, cara cebok yang tidak benar, stres yang berlebihan, merokok dan mengkonsumsi minuman keras, memakai bedak tabur/tisu/sabun yang berparfum di daerah genitalia serta sering menggunakan 
barang-barang pribadi secara bersamasama seperti perlengkapan mandi yang beresiko terjadi penularan keputihan. Dr. Boyke Dian Nugraha berpendapat hampir semua Perempuan di Indonesia pernah mengalami Fluor Albus minimal $1-2 \mathrm{x}$ seumur hidupnya $(6,7)$.

\section{Waktu Mengalami Keputihan}

Sebanyak $86 \%$ responden mengalami keputihan sebelum haid, $36 \%$ mengalami keputihan sesudah haid, $3 \%$ mengalami keputihan karena menggunakan pakaian ketat dan $35 \%$ keputihan karena kelelahan.

Cairan vagina diproduksi oleh tubuh untuk membersihkan organ kewanitaan. Dalam kondisi tertentu produksi cairan vagina dapat meningkat, seperti menjelang haid, sesudah haid, saat ovulasi, dalam kehamilan ataupun saat terangsang secara seksual. Hal ini terjadi karena pengaruh dari hormon kewanitaan (estrogen dan progesteron) $(8,9)$.

Penggunaan pakaian ketat sebaiknya dihindari, karena akan menghalangi udara masuk, menghambat aliran darah, serta menyebabkan keringat. Jika kondisi ini terjadi, maka jamur penyebab keputihan bisa lebih mudah berkembang biak. Disarankan untuk menggunakan celana yang longgar untuk menghindari keringat terlalu banyak divagina dan sirkulasi udara kedalam organ kewanitaan bisa lancer $(9,10)$.

Kejadian keputihan dapat pula disebabkan karena kelelahan atau stres. Pada saat kelelahan atau stres, akan menyebabkan perubahan sistem endokrin tubuh yang berpengaruh terhadap hormonal tubuh $(9,10)$.

Tanda-tanda keputihan patologis (Fluor Albus)
Sebanyak $83 \%$ responden pernah mengalami Fluor Albus, dengan tandatanda gatal (82\%), berbau (45\%), berwarna $(23 \%)$ dan mengeluh panas $(2 \%)$.

Keputihan umumnya disebabkan oleh jamur Candida Albicans, karena sifatnya yang parasit, jamur ini cenderung menimbulkan rasa gatal di sekitar daerah kewanitaan. Selain itu, jamur ini juga menimbulkan cairan keputihan dengan bau yang khas. Selain jamur, bakteri juga menjadi pemicu utama keputihan. Apabila jumlahnya banyak, dan cukup lama, bakteri ini bisa menyebabkan keputihan berlanjut menjadi penyakit yang lebih serius. Wanita yang kurang atau tidak menjaga kebersihan organ Kewanitaan sangat riskan untuk mengalami keputihan $(9,10)$.

\section{Pengaruh Pendidikan Kesehatan dengan Menggunakan Media Leaflet terhadap Perilaku Tentang Pencegahan Fluor Albus}

Notoatmodjo (2012) berpendapat bahwa perilaku merupakan respon seseorang yang berupa perbuatan atau tindakan yang dapat dicermati dan dipelajari. Perilaku dibagi menjadi dua bentuk, yaitu bentuk aktif dan bentuk pasif. Bentuk pasif merupakan respon yang tidak secara langsung terlihat oleh orang lain dan terjadi di dalam diri seperti pengetahuan, sikap dan persepsi (11).

Pada saat pretest, didapatkan mean perilaku $31,96 \%$ dan setelah mendapatkan penkes melalui leaflet mean perilaku meningkat menjadi 32,68 sehingga terjadi kenaikan mean 0,72. Setelah mendapatkan penkes melalui leaflet, sebagian besar responden memiliki perilaku yang lebih baik dalam melakukan pencegahan keputihan patologis.

Hasil penelitian ini mendukung penelitian Puspita Sari (2013) yang 
berjudul "Pengaruh Pendidikan Kesehatan Tentang Menstrual Hygiene terhadap Perubahan Perilaku Menstrual Hygiene Remaja Putri untuk Pencegahan Infeksi Saluran Reproduksi". Hasil penelitiannya menunjukkan terdapat perubahan yang signifikan perilaku menstrual hygiene setelah dilakukan Pendidikan Kesehatan tentang menstruasi ( $\mathrm{p}=0,0001)$ (12).

Penelitian ini sesuai dengan penelitian Yustisa dkk (2014) yang menyatakan terjadi perubahan perilaku siswa sekolah dasar tentang Perilaku Hidup Bersih dan Sehat sebelum dan sesudah diberi penkes dengan leaflet (13).

Leaflet menurut pembuatannya dan penggunaannya termasuk dalam alat peraga yang sederhana, yang mempunyai ciri-ciri antara lain gampang dibuat, mudah untuk mendapatkan bahan-bahannya, menggambarkan kebiasaan, kehidupan, dan kepercayaan setempat, didesain dengan sederhana, menggunakan Bahasa yang familiar sehingga dapat dimengerti masyarakat dan sesuai dengan kebutuhan masyarakat dan petugas Kesehatan. Pada penelitian ini leaflet terbukti dapat mengubah sikap mahasiswa kebidanan terhadap pencegahan fluor albus, hal ini dikarenakan leaflet mempunyai kelebihan antara lain: awet, dapat dimanfaatkan oleh banyak orang, murah / tidak mahal, tidak menggunakan listrik, bisa dibawa kemanamana, memiliki unsur estetika, mudah untuk dipahami dan meningkatkan semangat belajar (14-16).

Pengaruh Pendidikan Kesehatan dengan Menggunakan Media Slide Power Point terhadap Perilaku Tentang Pencegahan Fluor Albus

Pada saat pretest, didapatkan mean perilaku 29,94 \% dan setelah mendapatkan penkes melalui slide power point mean perilaku meningkat menjadi 33,48 sehingga terjadi kenaikan mean 3,54. Setelah mendapatkan penkes melalui slide power point, sebagian besar responden memiliki perilaku yang lebih baik dalam melakukan pencegahan keputihan patologis.

Hasil penelitian ini didukung oleh penelitian Yustisa dkk (2014) yang menyatakan bahwa terdapat perubahan perilaku siswa Sekolah Dasar tentang Perilaku Hidup Bersih Sehat setelah mendapatkan penkes melalui slide power point ditandai dengan perubahan mean perilaku sebelum dan sesudah (13).

Power Point adalah salah satu program di Microsoft Office. Microsoft Office Power Point merupakan program aplikasi yang dibuat secara istimewa untuk memperlihatkan program multimedia. Hal ini disampaikan oleh Riyana (2008) yang menyatakan: Program Microsoft Office Power Point merupakan salah satu software yang diciptakan secara eksklusif untuk menyajikan program multimedia dengan menarik, gampang pembuatannya, gampang penggunaanya dan murah karena tidak menggunakan bahan baku selain alat penyimpan data $(16,17)$.

Media slide tergolong dalam kelompok gambar diam, tetapi ia termasuk media pandang dengar, media slide mempunyai kemampuan untuk: (1) Memungkinkan penekanan pada impresi fakta-fakta yang baru atau untuk mengembangkan pengertian suatu abstraksi; (2) Dapat merangsang peserta didik untuk meneliti bahan-bahan lebih lanjut; (3) membantu dalam mempelajari dan mengingat isi materi; (4) Gambargambar garis yang sederhana, misalnya gambar bagan, sering lebih membuat efektif dalam menyampaikan informasi dari pada dalam gambar foto; (5) Warna gambar dapat membantu untuk membuat daya tarik dalam memberi penekanan pada suatu 
masalah yang sedang dibicarakan; (6) Bantuan verbal atau simbol lainya sebagai alat bantu dalam gambar diam, dapat membantu untuk menimbulkan kejelasan $(16,17)$

\section{Efektifitas Pendidikan Kesehatan Terhadap Perubahan Perilaku Tentang Pencegahan Fluor Albus}

Berdasarkan uji multivariat didapatkan nilai $F=6,125$ dan $P=0,000$, sehingga dapat disimpulkan adanya perbedaan yang signifikan antara penkes dengan leaflet dan penkes dengan slide power point terhadap perubahan perilaku $(0,000<0,05)$. Media slide power point lebih efektif karena meannya lebih besar dari media leaflet $(33,48>32,68)$. Efektifitas pendidikan kesehatan dapat dilihat dari perubahan mean pada posttest dengan menggunakan leaflet sebesar 32,68, sedangkan menggunakan slide power point sebesar 33,48, sehingga terdapat selisih sebesar 0,8 .

Penggunaan leaflet dan slide power point sebagai media promosi kesehatan baik digunakan sehingga mampu menarik minat dan membuat mereka mampu menumbuhkan perilaku hidup sehat. Rahmawati (2007) mengatakan bahwa media dapat mempengaruhi perubahan perilaku responden kearah yang positif, karena didasari oleh pengetahuan dan pengalaman hidup responden. Perilaku yang didasari dengan pengetahuan yang dimiliki, akan lebih bertahan lama daripada perilaku yang tidak didasari oleh pengetahuan. Faktor-faktor yang mempengaruhi perilaku menurut Notoatmodjo (2012) adalah faktor internal meliputi pengetahuan, persepsi, emosi, motivasi dan sebagainya, dan faktor eksternal meliputi lingkungan sekitar yaitu manusia, sosial-ekonomi, kebudayaan, dan sebagainya $(18,19)$.

\section{SIMPULAN}

Pendidikan Kesehatan yang menggunakan media Leaflet dan slide power point dapat mempengaruhi perubahan perilaku terhadap pencegahan keputihan patologis. Penkes Slide Power Point lebih efektif dalam memberikan perubahan terhadap perilaku pencegahan keputihan patologis dibandingkan menggunakan media leaflet.

\section{UCAPAN TERIMA KASIH}

Penelitian ini dapat dilaksanakan dengan baik berkat bantuan dari berbagai pihak, untuk itu peneliti mengucapkan terima kasih kepada Direktur Poltekkes Kemenkes Jakarta III, Ketua Jurusan Kebidanan, Kaprodi D III Kebidanan dan para mahasiswa yang telah memberikan kerjasama yang baik dalam penelitian ini.

\section{KONFLIK KEPENTINGAN}

Peneliti tidak memiliki konflik kepentingan, dan tidak ada afiliasi atau koneksi dengan atau dengan entitas atau organisasi apa pun, yang dapat menimbulkan pertanyaan bias dalam diskusi dan kesimpulan naskah.

\section{REFERENSI}

1. Qomariyah SN, Amaliah L, Darwisyah SR. Infeksi saluran reproduksi (ISR) pada perempuan Indonesia. Darwisyah SR, Amaliah L, editors. Jakarta: Pusat Komunikasi Kesehatan Berperspektif Jender bekerjasama dengan Ford Foundation; 2001.

2. Yulfitria F. Faktor Yang Berhubungan Dengan Perilaku Pencegahan Keputihan Patologis Pada Mahasiswa Kebidanan Jakarta. Poltekkes Kemenkes Jakarta III; 2015.

3. Susanto A. Teori Belajar dan 
Pembelajaran. Jakarta: Prenada Media Group; 2016.

4. Prawirohardjo S. Ilmu Kebidanan. Jakarta: Yayasan Bina Puskata; 2010.

5. Badaryati E. Faktor-Faktor yang Mempengaruhi Perilaku Pencegahan dan Penanganan Keputihan Patologis pada Siswi SLTA atau Sederajat di Kota Banjarbaru Tahun 2012. Universitas Indonesia; 2012.

6. Kusmiran E. Kesehatan Reproduksi Remaja dan Wanita. Jakarta Selatan: Salemba Medika; 2012.

7. Siregar A. Jangan Sepelekan Keputihan by dr. Boike Dian Nugraha [Internet]. 2014. Available from: http//www.dokter.us

8. Manuaba I. Memahami Kesehatan Reproduksi Wanita. Jakarta: Ercon; 2009.

9. Rozaknasa. Penyebab Keputihan [Internet]. 2009. Available from: http//www.keputihan.com

10. IBG M. Keputihan Pada Remaja. Bandung: Remaja Rosdakarya; 2009.

11. Notoatmodjo S. Pendidikan dan Perilaku Kesehatan. Jakarta: Rineka Cipta; 2012.

12. Sugiarsi S. Pendidikan Kesehatan pada Kelompok Ibu PKK dalam Meningkatkan Pemahaman Masyarakat untuk Mencegah Penyakit Kanker Serviks. Maternal. 2011;4(4).

13. Putu FY, I Ketut A, I Nyoman Gede S. Efektifitas Penggunaan Media Cetak dan Media Elektronik dalam Promosi Kesehatan terhadap Peningkatan Pengetahuan dan Perubahan Sikap Siswa SD. J Kesehat Lingkung. 2014;4(1):2939.
14. Kawuriansari R, Dyah F, Mulidah S. Studi efektivitas leaflet terhadap skor pengetahuan remaja putri tentang Dismenorea di SMP Kristen 01 Purwokerto Kabupaten Banyumas. J Ilm Kebidanan [Internet]. 2010;1(1):108-22. Available from: http://stikba.ac.id/medias/journal/26 -34.pdf

15. Daryanto. Media Pembelajaran Perannya Sangat Penting dalam Mencapai Tujuan Pembelajaran. Yogyakarta: Gava Media; 2010.

16. Nurkhoiron. Efektifitas Pendidikan Kesehatan dengan Menggunakan Media Leaflet dan Media Slide Power Point terhadap Perubahan Pengetahuan, Sikap dan Perilaku Deteksi Dini Kanker Serviks pada Ibu-ibu PKK di Wilayah Kerja Puskesmas Kartasura Sukoharjo. Universitas Muhammadiyah Surakarta; 2014.

17. Riyana. Pemanfaatan OHP dan Presentasi dalam Pembelajaran. Jakarta: Cipta Agung; 2008.

18. Rahmawati I, Sudargo T, Paramastri I. Pengaruh penyuluhan dengan media audio visual terhadap peningkatan pengetahuan, sikap dan perilaku ibu balita gizi kurang dan buruk di Kabupaten Kotawaringin Barat Propinsi Kalimantan Tengah. J Gizi Klin Indones [Internet]. 2007 Nov 1;4(2):69. Available from: https://jurnal.ugm.ac.id/jgki/article/ view/17478

19. Notoatmodjo S. Promosi kesehatan dan ilmu perilaku. Jakarta: Rineka Cipta; 2012.

1. Qomariyah SN, Amaliah L, Darwisyah SR. Infeksi saluran 
reproduksi (ISR) pada perempuan Indonesia. Darwisyah SR, Amaliah L, editors. Jakarta: Pusat Komunikasi Kesehatan Berperspektif Jender bekerjasama dengan Ford Foundation; 2001.

2. Yulfitria F. Faktor Yang Berhubungan Dengan Perilaku Pencegahan Keputihan Patologis Pada Mahasiswa Kebidanan Jakarta. Poltekkes Kemenkes Jakarta III; 2015.

3. Susanto A. Teori Belajar dan Pembelajaran. Jakarta: Prenada Media Group; 2016.

4. Prawirohardjo S. Ilmu Kebidanan. Jakarta: Yayasan Bina Puskata; 2010.

5. Badaryati E. Faktor-Faktor yang Mempengaruhi Perilaku Pencegahan dan Penanganan Keputihan Patologis pada Siswi SLTA atau Sederajat di Kota Banjarbaru Tahun 2012. Universitas Indonesia; 2012.

6. Kusmiran E. Kesehatan Reproduksi Remaja dan Wanita. Jakarta Selatan: Salemba Medika; 2012.

7. Siregar A. Jangan Sepelekan Keputihan by dr. Boike Dian Nugraha [Internet]. 2014. Available from: http//www.dokter.us

8. Manuaba I. Memahami Kesehatan Reproduksi Wanita. Jakarta: Ercon; 2009.

9. Rozaknasa. Penyebab Keputihan [Internet]. 2009. Available from: http//www.keputihan.com

10. IBG M. Keputihan Pada Remaja. Bandung: Remaja Rosdakarya; 2009.

11. Notoatmodjo S. Pendidikan dan Perilaku Kesehatan. Jakarta: Rineka Cipta; 2012.

12. Sugiarsi S. Pendidikan Kesehatan pada Kelompok Ibu PKK dalam Meningkatkan Pemahaman Masyarakat untuk Mencegah Penyakit Kanker Serviks. Maternal. 2011;4(4).

13. Putu FY, I Ketut A, I Nyoman Gede S. Efektifitas Penggunaan Media Cetak dan Media Elektronik dalam Promosi Kesehatan terhadap Peningkatan Pengetahuan dan Perubahan Sikap Siswa SD. J Kesehat Lingkung. 2014;4(1):2939.

14. Kawuriansari R, Dyah F, Mulidah S. Studi efektivitas leaflet terhadap skor pengetahuan remaja putri tentang Dismenorea di SMP Kristen 01 Purwokerto Kabupaten Banyumas. J Ilm Kebidanan [Internet]. 2010;1(1):108-22. Available from: http://stikba.ac.id/medias/journal/26 -34.pdf

15. Daryanto. Media Pembelajaran Perannya Sangat Penting dalam Mencapai Tujuan Pembelajaran. Yogyakarta: Gava Media; 2010.

16. Nurkhoiron. Efektifitas Pendidikan Kesehatan dengan Menggunakan Media Leaflet dan Media Slide Power Point terhadap Perubahan Pengetahuan, Sikap dan Perilaku Deteksi Dini Kanker Serviks pada Ibu-ibu PKK di Wilayah Kerja Puskesmas Kartasura Sukoharjo. Universitas Muhammadiyah Surakarta; 2014.

17. Riyana. Pemanfaatan OHP dan Presentasi dalam Pembelajaran. Jakarta: Cipta Agung; 2008.

18. Rahmawati I, Sudargo T, Paramastri I. Pengaruh penyuluhan dengan media audio visual terhadap peningkatan pengetahuan, sikap dan 
perilaku ibu balita gizi kurang dan buruk di Kabupaten Kotawaringin Barat Propinsi Kalimantan Tengah. J Gizi Klin Indones [Internet]. 2007 Nov 1;4(2):69. Available from: https://jurnal.ugm.ac.id/jgki/article/ view/17478

19. Notoatmodjo S. Promosi kesehatan dan ilmu perilaku. Jakarta: Rineka Cipta; 2012. 